вже школа, а створити умови для безперервної освіти впродовж життя повинні суспільство і держава.

Аналізуючи категорію освіти в сучасному суспільстві, зазначимо, що визначення мети освіти на сучасному етапі полягає у всебічному розвитку людини як особистості й найвищої цінності суспільства, у збагаченні на цій основі інтелектуального, творчого, культурного потенціалу народу, підвищення його освітнього рівня, а також у забезпеченні народного господарства кваліфікованими фахівцями.

Модернізація сучасної освіти виявляється у пошуку нових шляхів розвитку освітніх систем; розробці й експериментальній перевірці моделей випереджувального розвитку навчальних закладів відповідно до розвитку суспільства; знаходженні рівноваги, оптимального співвідношення між «ринковістю» освіти і іiі головним завданням - навчанням, вихованням, розвитком особистості, підготовкою ії до життя в сучасному суспільстві, які неможливо реалізовувати лише за ринковими критеріями.

Зазначимо, що на розвиток та модернізацію системи освіти в сучасних умовах впливають такі чотири взаємопов'язані чинники: швидкозмінність і швидкоплинність процесів суспільного розвитку; соціально-економічні трансформації в суспільстві, що зумовили появу принципово нового для нашої економіки і соціального буття явища ринку праці; процеси глобалізації, які відгукнулися інтеграційними тенденціями в світі; інформаційний «вибух» у суспільстві, зумовлений появою нових інформаційних технологій і мультимедіа. Система освіти, виконуючи свою гуманістичну місію, має підготувати молоду людину до життя в сучасному відкритому світі. Тому розвиток $\mathrm{i}$ функціонування освіти зумовлені всіма чинниками й умовами існування суспільства: економічними, політичними, соціальними, культурними тощо.

Отже, людський розвиток, розвиток особистості, розвиток суспільства визначають саме зміст педагогічної категорії «освіта».

\title{
Література
}

1. Біла книга національної освіти України / за ред. В. Г. Кременя. - К. : ТОВ «Інформаційні системи», 2010. - 643 с. 2. Кремень В. Ключові завдання : утвердження пріоритетності і модернізація освіти / В. Кремень // Дошк. виховання. 2001. - № 11. - С. 5. 3. Педагогіка / під. ред. М. Д. Ярмаченка. - К. : Вища школа, 1986. - 543 с. 4. Песталоцці Й. Вибрані твори/ За ред. М. І. Гордієвского,
А. Г. Готалова-Готріба і
В. О. Чудновцева. -
Одеса,
1928. -
C. 67.

5. Степанова Т. М. Трансформації змісту передшкільної освіти в історії розвитку вітчизняної дошкільної педагогіки (кінець XIX-XX століття): [монографія]/ Т. М. Степанова. - К. : Видавничий Дім «Слово», 2011. - 424 с. 6. Харламов И.Ф. Педагогика / И. Ф. Харламов. - Минск, 1979. - 101 с.

\section{ОСНОВНІ ПЕРЕДУМОВИ ЕКОНОМІЧНОЇ ОСВІТИ У ШКОЛАХ ТЕХНОЛОГІЧНОГО ПРОФІЛЮ НАВЧАННЯ}

Кулішов В. С. Основні передумови економічної освіти у школах технологічного профілю навчання.

У статті здійснено спробу розкрити основні передумови й обгрунтувати актуальність створення системи економічної освіти i виховання у школах 3 технологічним профілем навчання.

Ключові слова: економічна освіта, проектно-технологічна діяльність учнів, сталий розвиток, синергетика, профільна економічна підготовка. 
Кулишов В. С. Основные предпосылки для экономического образования в школах технологического профиля обучения.

В статье осуществлена попытка раскрыть основные предпосылки и обосновать актуальность создания системы экономического образования и воспитания в школах с технологическим профилем обучения.

Ключевые слова: экономическое образование, проектно-технологическая деятельность учащихся, устойчивое развитие, синергетика, профильная экономическая подготовка.

Kulishov V. S. The basic preconditions for economic education in schools majoring in technology.

The article highlights the basic preconditions as well as substantiates the great importance of creating the system of economic education in schools majoring in technology.

Key words: economic education, project and technological activity of schooldren, sustainable development, synergy, major in economics.

В умовах глобалізаційних та інтеграційних процесів економіки співробітництво між країнами набуває нового сенсу. На цьому фоні вітчизняна економіка вимагає значного підвищення конкурентоспроможності, інноваційних проектів юридичних та фізичних осіб, застосування сучасних методів підготовки учнівської молоді до трудової і професійної діяльності.

3 огляду на це зрозуміло, що формування усебічно розвиненої, самодостатньої особистості неможливе без системи економічної освіти та виховання у школах технологічного профілю навчання, оскільки здатність проводити економічні операції закладається не лише на уроках математики, географії чи суспільствознавства, а, в першу чергу, у проектно-технологічній діяльності учнів, що має характер найбільш практичного застосування економічних знань. I навпаки - жодне завдання економічної освіти та виховання не може реалізуватись у відриві від проектнотехнологічної діяльності. Йдеться про справжнє, а не формальне включення учнів у проектно-технологічні виробничі відносини для того, щоб в учнів формувалися життєві повноцінні уявлення про працю, іiі характер, трудову дисципліну, зарплату, собівартість, попит. Настав час звернути увагу старшокласників на економічний складник об' єктів проектно-технологічної діяльності.

Проблему формування економічних знань у процесі трудової підготовки підростаючого покоління у своїх працях неодноразово обгрунтовували відомі науковці: А. Аменд, І. Сасова [12], В. Мадзігон [6], А. Нісімчук [9], І. Прокопенко [11], Д. Тхоржевський [13], О. Шпак [14]. Однак аналіз сучасного стану економічної освіти свідчить про те, що зазначені напрацювання так і не були системно впроваджені у шкільний навчальний процес, у тому числі на профільному рівні.

Метою статmі є спроба розкрити основні передумови й обгрунтувати актуальність створення системи економічної освіти у школах 3 технологічним профілем навчання.

Новою парадигмою розвитку суспільства $є$ парадигма сталого розвитку, яку доцільно розуміти не лише в контексті зміни стосунків людини і природи задля розширення можливостей економічного зростання, а як скоординовану глобальну стратегію виживання людства, орієнтовану на збереження і відновлення природних спільнот у масштабах, необхідних для повернення до меж господарської місткості біосфери. Концепція сталого розвитку сьогодні набуває значного поширення як одна 3 
провідних глобальних проблем людства, що має міждисциплінарний характер i розглядається в багатьох аспектах і ракурсах, найважливішими з яких $\epsilon$, як мінімум, дві ідеї:

- цей розвиток передбачає вирішення економічних, соціальних та екологічних проблем. Розвиток буде сталим тільки тоді, коли буде досягнута рівновага між різними факторами, що зумовлюють загальний рівень життя;

- сучасне покоління має обов'язком перед наступними поколіннями залишити достатні запаси соціальних, природних та економічних ресурсів для того, щоб вони могли забезпечити для себе рівень добробуту не нижчий, ніж той, що ми маємо на сучасному етапі розвитку цивілізації.

У зв'язку 3 цим, для самоорганізації будь-якої системи сучасною філософією необхідними виявлені нелінійність, когерентність, відкритість - властивості синергетичної методології пізнання довкілля. Синергізм (діючий разом) розуміється нами як явище посилення дії одного каталізатора через додавання іншого. Нині синергетика, як зазначає В. Кремень, долаючи міждисциплінарний статус, швидко перетворюється на відповідального носія нової парадигми стилю мислення. Нова методологія втілюється в техніку, мистецтво, економіку i, безумовно, повинна проникати в освіту [4, с. 5].

Таким чином, утверджується принципово новий тип суспільного прогресу, названий інноваційним типом, а це динамічні зміни обставин життя, глобальна інформатизація, прорив новітніх технологій. Це все означає, що неможливо раз і назавжди навчити дитину на все життя в будь-якому навчальному закладі. Вченимипедагогами доведено, що недостатньо зосереджувати увагу в школі лише на засвоєнні певної суми знань. Треба домогтися реалізації у ході навчального процесу ще однієї функції - навчити молодь бути освіченою впродовж життя, самостійно засвоювати нові знання і нову інформацію, виробити потребу в цьому, а отже, навчити підростаюче покоління адаптуватись до вимог суспільства ринкових відносин. Відповіддю сучасної освіти на стихійний адаптивний процес стала система економічної освіти, що активно розвивається на всіх етапах навчання.

Нинішня динамічність життя вимагає постійного вдосконалення існуючих систем навчання, у тому числі й економічної освіти у нашій країні з урахуванням компетентнісного й особистісно зорієнтованого підходів. I прерогатива тут належить профільним школам, коледжам, університетам, які мають дати майбутнім фахівцям особистісно-ціннісні та сенситивно-доцільні знання з економіки, основ виробництва матеріальних благ, професійні знання глобальних процесів ринкової економіки, професійні знання із підприємництва, бізнесу, фінансової системи, менеджменту і маркетингу, інтелектуальної власності та інших важливих курсів [5, с. 9].

Ми погоджуємось із думкою М. Вачевського та О. Падалки про те, що економічна освіта $\epsilon$ складовою частиною виховання гармонійно розвинутої особистості, має специфічні завдання, принципи, проникає у всі напрямки суспільного життя [1, с. 35]. Педагогічно доцільною економічна освіта $\epsilon$ саме на заняттях старшокласників 3 технологій, де учні мають змогу художньо проектувати вироби з урахуванням трьох обов'язкових характеристик: функціональної, естетичної i економічної. При цьому економічну характеристику виробу, який проектується, варто виокремити як пріоритетну.

Отже, необхідно забезпечити проектно-технологічний підхід до методики навчання старшокласників основ економіки у загальноосвітніх навчальних закладах технологічного профілю. Адже предметною компетентністю з технологій $\epsilon$ проектнотехнологічна, про що зазначається у стандартах базової і повної середньої освіти [2], а 
однією з ключових виокремлено підприємницьку компетентність.

У ході дослідження 3'ясовано, що за сучасних умов розвитку нових тенденцій соціально-економічної діяльності особливо актуальною є проблема формування i розвитку особистості готової працювати компетентно у відповідній професійній сфері. Завданням профільної школи, як початкової ланки неперервної економічної освіти, є поєднання загальної середньої освіти учнів 3 поглибленим засвоєнням економічних знань і вмінь практично застосовувати їх у допрофесійній і майбутній професійній діяльності. Економічна підготовка учнів профільних класів до технологічної діяльності та роботи в умовах ринкової економіки потребує оволодіння ними організаторськими уміннями, творчими підходами й активною життєвою позицією, орієнтованими, зокрема, на співробітництво, підприємництво, комунікативність, прийняття рішень, адаптивність до демократичних форм організаторської діяльності.

Отже, перехід українського суспільства до ринкових відносин вимагає кардинальних змін у трудовому й економічному вихованні школярів. На перший план виступають такі якості особистості, як самостійність і підприємливість, які мають безпосереднє ставлення до практико-орієнтованого i проектно-технологічного підходів до навчання основ економіки старшокласників.

Підприємливість - особливий новаторський стиль господарської поведінки, в основі якого лежить постійний пошук нових можливостей для розвитку своєї справи. Складовими підприємливості є: високий професійний рівень, критична оцінка своєї діяльності, оптимізм, незалежність у міркуваннях, уміння розпочинати і вести справу, генерувати нові ідеї та їх реалізовувати, готовність до інновацій, схильність до ризику, уміння долати перешкоди, обгрунтування рішень, що приймаються, підтримання гармонійних стосунків із колективом, партнерами, вірність даному слову, взятим зобов'язанням [8, с. 404].

Однак, життя доводить, що переважна більшість учнів-випускників не володіє основами підприємницької діяльності, теоретичними знаннями 3 економіки, менеджменту, маркетингу, реклами, фінансів, банківської справи, вони губляться у непередбачуваній ринковій ситуації й не можуть практично реалізувати свої вміння, знання та навички.

Підприємництво - це нова для нас діяльність і за формою, й за змістом, це одна 3 основних граней професійної трудової діяльності людини. Оволодіння нею потребує не просто засвоєння певної суми знань, а синтезу розумових i практичних можливостей, соціально-біологічної зрілості особистості, виявлення важливої риси уміння бути собою. Тому набуття ділових якостей допомагає дитині реалізуватися в пізнанні нових граней життя і водночас своєї індивідуальності. У процесі профільної економічної підготовки учні вчаться самовияву, бути реалістами, перемагати, не засліпнувши від успіху, і переживати невдачі, не впадаючи в розпач, самостійно думати й застосовувати знання в нових ситуаціях.

Багато науковців розглядають підприємництво та підприємливість як дар, талант, натхнення чи навіть «прозріння». Фахівці дослідили, що природну (вроджену) здатність до підприємницької діяльності має не так багато людей (близько $5 \%$ населення) у будь-якій країні. Однак часто більшість із нас навіть не здогадується, які здібності закладені в нас природою і як їх можна розвинути у процесі навчання та практичної діяльності. Тому в цій справі, як і в будь-якій іншій, важливими є освіта й саморозвиток [3, с. 16]. Академік НАПН України І. Прокопенко пропонує, наприклад, визначати економічну культуру у зв'язку 3 культурою підприємництва. Однією з основних якостей, що визначає професійний рівень 
підприємця, є характер ділового спілкування при вирішенні різних комерційних проблем. Основними показниками, що дозволяють визначити рівень економічної культури, $€$ наявність моральних якостей, таких як чесність, порядність, відповідальність, чуйність, мобільність, комунікабельність, діловитість, ініціативність, сумлінність, спритність, хитрість. Ринкові відносини передбачають поєднання підприємництва та духовної культури, які можна визначити як економічну етику чи ділову етику, або культуру підприємництва [11, с. 35].

Велике значення має, на наш погляд, практичне впровадження елементів підприємницької діяльності в навчальний процес. Це може досягатися як за допомогою ділових ігор безпосередньо на заняттях, так і при навчанні в ході випуску корисної продукції, яка може бути креативно представлена та реалізована покупцеві, $\mathrm{i}$ в позаурочний час - під час роботи в різних комерційних структурах. Варто також зазначити, що тісний взаємозв'язок професійних якостей підприємця і моралі випливає безпосередньо з самої суті підприємницької діяльності. Бізнес- це безперервні контакти, відносини, переговори 3 партнерами, постачальниками i споживачами товарів. Ділові стосунки в багатьох випадках доводиться будувати не лише на юридичних документах, а в більшій мірі на взаємній довірі. Оптимальний засіб забезпечення чесного підприємництва, як зазначає О. Набока, - виховання культури, починаючи з раннього дитинства, почуття моральної відповідальності за свої вчинки. Людина, якій притаманні віра в справедливість, у якій виховано почуття сорому за нечесні вчинки і яка керується принципами релігійної моралі, заповідей закону Божого, не здатна будувати свій бізнес на обмані інших. Розквіт у бізнесі повинен бути пов'язаний 3 високим рівнем моральності підприємців, підпорядкований принципам ділової етики [7, с. 24].

Формування знань, умінь, навичок та якостей підприємця здійснюється на теоретичних i практичних заняттях, які перебувають у тісному взаємозв'язку 3 уроками трудового навчання, курсами по освоєнню тієї чи іншої професії, позакласною діяльністю, суспільно корисною продуктивною працею учнів. Що стосується останнього, то 3 економічної точки зору продуктивність означає досягнення цілей організації при мінімумі витрат і зусиль, тобто продуктивний менеджер використовує людські і матеріальні ресурси 3 найвищим результатом [8, c. 435]. Тому основна ідея нової системи технологічної та економічної освіти учнівської молоді - поєднання навчання з індивідуальною та колективною суспільно корисною, продуктивною працею чи громадською діяльністю. Сутність технологічної та економічної профільної освіти учнівської молоді полягає у формуванні в неї готовності до самостійного життя та праці, яка виявляється у підприємницькій діяльності і культурній самореалізації учнів. Відповідно до цього кожна молода людина, що стає на шлях самостійного трудового життя, повинна мати всебічний інтелектуальний та фізичний розвиток, наукове світосприйняття, глибокі знання науково-технічних та економічних основ сучасного виробництва, а також свідомо і творчо долучатися до суспільно корисної та продуктивної праці [6, с. 32].

В умовах профілізації старшої школи актуальним стає питання наступності викладання профільних дисциплін у старших класах загальноосвітньої школи, професійно-технічних училищах, коледжах та ВНЗ відповідного профілю. Тому економічна освіта і виховання молоді шляхом неперервності є парадигмою нових технологій навчального процесу та формування економічної компетентності майбутніх фахівців, які надає освіта в реаліях сьогодення. Впровадження безперервної економічної освіти в школі, як важливий фактор модернізації освітньої системи, дає можливість створити єдиний освітній економічний простір, забезпечити послідовність 
у навчанні основ економіки, дати можливість поетапно опановувати економічні знання. Звідси виникає потреба в об'єднанні зусиль середньої і вищої школи для розробки та реалізації освітньо-професійних програм, розвитку профорієнтаційної мобільності.

Викладене вище дозволяє зробити таке узагальнення: для продуктивного, якісного забезпечення безперервності економічної освіти слід до системи профільної економічної підготовки учнів врахувати окремі аспекти професійної економічної підготовки з іiі практико-орієнтовною і проектно-технологічною спрямованістю. На нашу думку, елементи професійної підготовки реалізують якісні зміни у змісті, структурі і методиці організації навчально-виховного процесу з метою підготовки старшокласників до корисної та ефективної діяльності, формування самодостатньої особистості, здатної брати на себе відповідальність і бути конкурентоспроможною в умовах ринкової економіки.

Одним із першочергових завдань сучасної економічної підготовки стає формування конкурентоздатного спеціаліста нової генерації молоді, спроможного до ефективної самореалізації в ринкових умовах розвитку суспільства, якому притаманне уміння бачити наперед, об'єктивно оцінювати майбутнє і виконувати відповідні дії, який добре розуміє особливості сучасного і майбутнього економічного розвитку України, прогнозує шляхи розвитку економіки нашої держави в контексті світових інтеграційних процесів.

У свою чергу, сучасний підхід до використання робочої сили грунтується на потребі формування багатопрофільного працівника, котрий поєднує різні спеціальності та види трудової діяльності з постійним підвищенням рівня освіти i професійної підготовки. Оскільки ринкова економіка передбачає реструктуризацію механізмів господарювання, розширення сфер діяльності людини, розвиток виробничої та споживчої конкуренції, постають нові вимоги до економічної підготовки професійних кадрів, серед яких Т. Поясок виокремлює такі:

- здатність до роботи в умовах багатоскладної економіки, функціонування організаційних утворень різних форм власності і господарювання;

- висока адаптованість до нових потреб підприємницької діяльності суб'єктів;

- здатність до впровадження інновацій і постійного самовдосконалення;

- здатність впевнено працювати за надзвичайних умов і успішно реалізовувати антикризову політику;

- уміння використовувати в професійній діяльності комп'ютерну техніку, сучасні інформаційні технології та інші нововведення [10, с. 25].

Вимогою часу є навички організаційної діяльності. Схильність до організаційної діяльності передбачає самостійне включення в неї, потребу в ііі здійсненні, постійну готовність до іiі виконання, емоційно-позитивне самопочуття при іiі виконанні й почуття незадоволення за відсутності такої активності. Найчастіше ця якість актуалізується особистістю в процесі заняття підприємницькою діяльністю.

Відчутними також є деякі зміни в формуванні економічного мислення. Його значення в процесі економічної підготовки фахівця до практичної діяльності важко переоцінити. Набуті знання не можуть бути зафіксовані, а згодом практично використані без розумових дій. Розвиток мислення має велике значення у формуванні особистості майбутнього спеціаліста. Більшість професійних завдань, які розв'язує сучасний спеціаліст, мають особливості загальної специфіки практичного мислення. Це, насамперед, проблемні ситуації, що виникають, як правило, несподівано.

Важливим та об'єднувальним складником сучасної економічної підготовки є 
формування та розвиток економічної культури учнів на рівні професійних вимог. Обгрунтування аналізованої категорії зумовлено необхідністю реорганізації основних характеристик економічних відносин у соціумі, які виникають між людьми стосовно виробництва, обміну, розподілу і споживання матеріальних благ. Актуалізуючи відомості про економічну культуру, звертаємо увагу на недостатнє висвітлення економічного складника в культурі проектно-технологічної діяльності старшокласників у процесі профільного навчання.

Реалізація потенціалу творчої особистості в умовах ринкової конкуренції неможлива також без економічної, юридичної, комп'ютерно-інформаційної, педагогічної та психологічної грамотності, інтеграційна суть яких $\epsilon$ базою функціональної кваліфікації сучасного спеціаліста. Теорія свідчить, а практика доводить необхідність домагатися цілісного, системного сприйняття всього комплексу навчальних дисциплін з орієнтацією на практичний досвід, що відповідає поступовому розвитку кваліфікаційних навичок і професійних знань в учнів. Інтелект особистості стає не лише формою власності, але й основою для створення і нагромадження добробуту як окремої особистості, так і цілих фірм, компаній, держав і корпорацій, у яких рівень освіти працівників $\epsilon$ характерною ознакою нинішнього етапу прискореної глобалізації та регіоналізації світової економіки. У зв’язку з цим, у процесі профільної економічної підготовки провідної ролі набуває поняття інтелектуалізації праці, в першу чергу - фізичної, а також наукових підходів до організації цього процесу. Проте, старшокласники мало ознайомлені із законом про інтелектуальну власність. Вони часто не вважають свої технічні і художні проекти інтелектуальною власністю, яку варто розглядати і в економічному контексті.

Профільна економічна підготовка учнів має відповідати сучасним вимогам ринкових відносин, світовим тенденціям економічного і суспільного розвитку. Досягнення подібних цілей передбачає розробку й обгрунтування нових підходів до методики навчання економічних дисциплін на основі теоретичних джерел, матеріалів експериментальних досліджень i творчих пошуків. Результатом профільної економічної підготовки повинно бути не лише отримання стабільних та грунтовних знань, умінь та навичок, які зводяться до суто предметних, а й здатність упровадження їх на практиці.

Для забезпечення ринку праці України кваліфікованими трудовими ресурсами необхідне створення умов для навчання та підготовки, перепідготовки, підвищення кваліфікації фахівців за допомогою сучасних засобів зв'язку та новітніх інформаційних технологій. Неперервність економічної освіти відкриває перед особистістю можливість постійно поглиблювати загальноосвітні та спеціальні економічні знання, сприяє досягненню цілісності й наступності у навчанні, перетворенню його у процес, що триває протягом усього життя людини.

Отже, профільна економічна підготовка учнів старшої школи, що є першою сходинкою процесу неперервної економічної освіти, є вимогою часу та необхідним складником проектування ефективного i конкурентоспроможного спеціаліста, здатного як до виконання певних обов'язків і гнучкості при їх видозміні, так і до успішного управління компанією в умовах глобалізованого ринку з його динамікою, автоматизацією усіх сфер життя, високим рівнем технологій. Зростання ролі особистості як професіонала i громадянина в удосконаленні господарського, соціального та культурного життя суспільства спонукає до розробки абсолютно нових підходів до економічної освіти і виховання підростаючого покоління. 


\section{Література}

1. Вачевський М. В. Педагогічні технології економічної та маркетингової освіти у початковій i основній школі: [монографія]/ за науковою редакцією М. В. Вачевського. - К. : Каравела, 2013. - 344 с. 2. Державний стандарт повної загальної середньої освіти [Електронний ресурс]. Режим доступу: http://mon.gov.ua/ua/activity/education/56/general-secondary education/ state_standarts 3. Калініна Н. Розвиток підприємливості в учнів / Н. Калініна // Завуч. - 2009. № 10. - С. 16-17. 4. Кремень В. Синергетична модель розвитку освіти як відповідь на виклики сьогодення / В. Кремень // Рідна школа. - 2010. - № 6. - С. 3-6. 5. Кулішов В. В. Методичні засади формування економічної компетентності у процесі підготовки фахівців технологій: [монографія] / В. В. Кулішов. - К. : Каравела, 2011. - 567 с. 6. Мадзігон В. М. Продуктивна педагогіка: [монографія] / Василь Мадзігон. - К. : Вересень, 2004. - 324 с. 7. Набока О. Навчання і виховання майбутніх підприємців / О. Набока // Рідна школа. - 1999. - № 9. - С. 24 -28. 8. Навчальний економічний словник-довідник: терміни, поняття, персоналії / за наук. ред. Г. I. Башнянина i $\quad$ В. С. Іфтемчука. - Львів: «Магнолія 2006», 2007. - 688 с. 9. Нисимчук А. С. Экономическое образование школьников [Текст]: Кн. для учителя / А. С. Нисимчук. - М : Просвещение, 1991. - 128 с. 10. Поясок Т. Сучасний стан професійної підготовки майбутніх економістів у незалежній Україні / Т.Поясок // Неперервна професійна освіта: теорія і практика. - 2007. - Вип. 1/2. - С. 25-31. 11. Прокопенко И. Ф. Экономическое образование школьников / И. Ф. Прокопенко, Е. Н. Камышанченко, $\quad$ В. И. Лозовая. - $\quad$ Харьков: Основа, $1993 .-170$ с. 12. Сасова И. А. Экономическое воспитание школьников в процессе трудовой подготовки / под ред. В. К. Розова. - М. : Просвещение, 1988. - 190 с. 13. Тхоржевський Д. О. Методика трудового та професійного навчання: [підручн. для вищ. пед. навч. закл.] / Д. О. Тхоржевський / НПУ ім. М. П. Драгоманова. - К. : Видавництво НПУ ім. М. П. Драгоманова, 2004. - 320 с. 14. Шпак О. Т. Вивчення і оцінка рівня економічної підготовки учнів: питання теорії і методики: [навч. посіб.] / О. Т. Шпак, С. Г. Цибін, В. М. Городній, В. І. Терес; НПУ ім. М.П.Драгоманова. К. : Четверта хвиля, 2001. - 127 с.

УДК 371.383

Ірина Максименко, Олена Пінська

\section{ТЕХНІКА МОВЛЕННЯ ЯК ЕЛЕМЕНТ МОВЛЕННЕВОЇ МАЙСТЕРНОСТІ МАЙБУТНІХ ПЕДАГОГІВ}

Максименко І. Г, Пінська О. Л. Техніка мовлення як компонент мовленнєвої майстерності майбутніх педагогів.

У статті розкривається сутність техніки мовлення, іiі зміст; характеризуються структурні компоненти; висвітлюється роль техніки мовлення в педагогічній діяльності, типові помилки та обгрунтовуються шляхи іï формування.

Ключові слова: педагогічна майстерність, педагогічна техніка, техніка мовлення, мовленнєве дихання, властивості голосу, дикція, інтонація.

Максименко И. Г., Пинская Е. Л. Техника речи как компонент речевого мастерства будущих педагогов.

В статье раскрывается сущность техники речи, ее содержание; характеризуются структурные компоненты; освещается роль техники речи в педагогической деятельности, типичные ошибки и обосновываются пути ее формирования. 